\title{
Uréia em suplementos protéico-energéticos para bovinos de corte durante o período da seca: características nutricionais e ruminais ${ }^{1}$
}

\author{
Eduardo Henrique Bevitori Kling de Moraes ${ }^{2 *}$, Mário Fonseca Paulino ${ }^{3}$, Kamila Andreatta \\ Kling de Moraes ${ }^{4}$, Sebastião de Campos Valadares Filho ${ }^{3}$, Joanis Tilemahos Zervoudakis ${ }^{5}$, \\ Edenio Detmann ${ }^{3}$
}

\footnotetext{
${ }^{1}$ Apoio: FAPEMIG.

2 Doutorando, DZO/UFV. Bolsista do CNPq.

${ }^{3}$ DZO/UFV, Viçosa, MG, CEP: 36570-000.

4 Doutoranda DZO/UFV. Bolsista da CAPES.

${ }^{5}$ DPA/UFMT, Cuiabá, MT, CEP: 78060-900.
}

RESUMO - Objetivou-se avaliar o consumo, a digestibilidade, o pH e a concentração de amônia do líquido ruminal, a concentração de nitrogênio sérico e urinário e a síntese microbiana em novilhos recebendo suplemento durante o período da seca. Utilizaram-se quatro novilhos mestiços Zebu $\times$ Holandês, castrados, com peso médio inicial de $430 \mathrm{~kg}$, fistulados no esôfago, rúmen e abomaso e distribuídos em quatro piquetes de Brachiaria decumbens, cada um com 0,40 ha. Cada animal recebeu 4,0 kg/dia de suplemento, constituído de milho moído, farelo de algodão, mistura mineral e uréia/sulfato de amônia em quatro níveis $(0 ; 1,2 ; 2,4$ e 3,6\% na matéria natural). Os consumos de matéria seca total, 2,0\% (10,9 kg/dia), e de pasto, 2,3\% (7,1 kg/dia), matéria orgânica, 2,2\% (9,7 kg/dia), matéria orgânica do pasto, 2,3\% (6,3kg/dia), proteína bruta, $1,9 \%$ (1,3 kg/dia), extrato etéreo, 3,6\% (0,4 kg/dia), fibra em detergente neutro, 1,9\% (5,8 kg/dia), carboidratos totais, 2,3\% (8,2 kg/dia), e carboidratos não-fibrosos, 2,9\% (4,1 kg/dia), foram influenciados de forma quadrática pelos níveis de uréia nos suplementos. Apenas a digestibilidade total da matéria orgânica foi afetada, de forma linear positiva, pelos níveis de uréia no suplemento. Não foram observados efeitos dos níveis de uréia no suplemento sobre o pH ruminal, entretanto as concentrações de amônia aumentaram linearmente de acordo com os níveis de uréia, ocasionando aumento linear na excreção de nitrogênio sérico e urinário. A eficiência microbiana, em qualquer forma de expressão, não diferiu entre os níveis de uréia.

Palavras-chave: amônia, consumo, digestibilidade, pH, nitrogênio não-protéico, suplementação protéica

\section{Urea in protein-energy supplements for beef cattle during the dry season: nutritional and ruminal traits}

\begin{abstract}
Four Zebu $\times$ Holstein steers were fistulated in rumen, abomasums and esophagus, with $430 \mathrm{~kg}$ of live weight grazing in four paddocks of Brachiaria decumbens (.40 ha), feed supplements were used to evaluate intake, digestibility, $\mathrm{pH}$ and ammonia ruminal concentration, nitrogen in serum and urine and microbial yield. The animals received $4.0 \mathrm{~kg} /$ animal/day of supplement based on grounded corn grain, cottonseed meal, mineral mix (MM), ammonium sulfate and urea in four levels (0, 1.2, 2.4 and 3.6\%) as fed basis. The intake of total (TDM) and pasture (DMP) dry matter, organic matter $(\mathrm{OM})$, OM from pasture, crude protein (CP), ether extract (EE), neutral detergent fiber (NDF), total carbohydrate (TO) and non-fiber carbohydrate (NFC) presented quadratic behavior. The maximum responses on the urea levels were: $2.0 \%$ (10.9 kg/day), 2.3\% (7.1 kg/day), 2.2\% (9.7 kg/day), 2.3\% (6.3 kg/day), 1.9\% (1.3 kg/day), 3.6\% (0.4 kg/day), $1.9 \%$ (5.8 kg/day), 2.3\% (8.2 kg/day) and 2.9\% (4.1 kg/day), respectively, for TDM, DMP, OM, OMP, CP, EE, NFD, TC and NFC. The OM digestibility was affected with a linear behavior. No differences were observed for the pH values. However, ammonia concentration increased linearly as the urea level in the supplement increased. The urea level in supplement increased linearly the nitrogen in serum and urinary excretion of nitrogen from urea. No effect from the urea level on the microbial efficiency, expressed by different forms, was observed.
\end{abstract}

Key Words: ammonia, digestibility, intake, non protein nitrogen, $\mathrm{pH}$, protein supplementation 


\section{Introdução}

Nos sistemas de produção de bovinos em pastejo, principalmente durante a seca, a lenta degradação dos componentes fibrosos potencialmente degradáveis das forragens é o primeiro fator limitante dos processos digestivos no rúmen e que compromete o desempenho produtivo e reprodutivo dos animais.

Nestas circunstâncias, é fundamental o fornecimento de substratos essenciais limitantes via suplementação para acelerar a digestibilidade da fração fibrosa e aumentar a taxa de passagem da fração indigestível da forragem, que tem reflexos positivos sobre o consumo e o desempenho dos animais (Moraes et al., 2006).

Contudo, o suplemento não deve fornecer nutrientes em quantidade superior às exigências nutricionais dos animais para não aumentar nem ocasionar efeito substitutivo. Normalmente, a ingestão de suplementos altera a quantidade de forragem consumida, portanto, a direção e a extensão da mudança dependem da qualidade da forragem e do tipo de suplemento. Em geral, suplementos protéicoenergéticos aumentam o consumo e a digestibilidade de forragens de baixa qualidade, propiciando o ganho de peso.

No entanto, a produtividade não deve comprometer a sustentabilidade do sistema de produção (Moraes et al., 2006). A uréia tem sido incluída na formulação de suplementos para bovinos com os objetivos de substituir a proteína vegetal, de alto custo, e acrescentar nitrogênio (N) em sistemas de produção em pastejo com forragem de baixa qualidade. Desta forma, sua utilização tem sido foco de pesquisas (Rennó et al., 2005; Paixão et al., 2006), pois possui menor custo por unidade de equivalente protéico.

Neste contexto, reduzir as perdas de compostos nitrogenados torna-se fundamental para maior aproveitamento dos alimentos e síntese de proteína microbiana. Muitos fatores afetam a eficiência de síntese de proteína microbiana e as disponibilidades de energia e nitrogênio são os principais determinantes desse processo (Moscardini et al., 1998).

Segundo Magalhães et al. (2005), as recomendações sobre a utilização de uréia em concentrados para bovinos não são adequadas, uma vez que níveis superiores aos recomendados têm melhorado o desempenho dos animais. Além disso, há escassez de trabalhos na literatura nacional sobre os níveis ideais de uréia em suplementos protéicoenergéticos e que não afetam as características nutricionais e ruminais de bovinos criados no sistema pasto-suplemento durante o período da seca.
Desta forma, objetivou-se avaliar os efeitos de níveis de uréia em suplementos protéico-energéticos sobre o consumo, a digestibilidade, o pH, a concentração de amônia do líquido ruminal, as concentrações de nitrogênio sérico e urinário e a síntese microbiana em novilhos em pastejo no período da seca.

\section{Material e Métodos}

O experimento foi realizado na Central de Experimentação, Pesquisa e Extensão do Triângulo Mineiro da Universidade Federal de Viçosa, localizada no município de Capinópolis, Minas Gerais, durante o período da seca, entre os meses de julho e setembro de 2001.

Utilizaram-se quatro novilhos mestiços Zebu × Holandês, castrados, com peso vivo (PV) médio inicial de $430 \mathrm{~kg}$, fistulados no esôfago, rúmen e abomaso. O experimento foi composto de quatro períodos experimentais com 15 dias de duração, de modo que os 7 primeiros dias foram destinados à adaptação dos animais aos suplementos.

A área experimental constituiu-se de quatro piquetes de 0,40 ha, formados com a gramínea Brachiaria decumbens Stapf., providos de bebedouro e comedouro coberto. A pastagem foi vedada ao pastejo (diferimento) a partir de 15 de março de 2001 para que houvesse disponibilidade de forragem durante a seca.

Avaliaram-se suplementos protéico-energéticos contendo uréia/sulfato de amônio (9:1) em quatro níveis 0 ; 1,2; 2,4 e 3,6\% na matéria natural em substituição ao farelo de algodão (Tabela 1). Os suplementos foram fornecidos diariamente em comedouro individual, às $10 \mathrm{~h}$, na quantidade de $4,0 \mathrm{~kg} / \mathrm{animal}$.

Realizaram-se coletas de amostras do pasto nos piquetes a cada 15 dias pelo corte, a $10 \mathrm{~cm}$ do solo, de cinco áreas delimitadas por um quadrado metálico de $0,5 \times 0,5 \mathrm{~m}$. Após a pesagem, as amostras foram homogeneizadas retirando-se duas alíquotas compostas, uma para avaliação da disponibilidade total de matéria seca/ha (MST) e outra para análise

Tabela 1 - Composição dos suplementos (\%) com base na matéria natural

\begin{tabular}{lcccc}
\hline Item & \multicolumn{4}{c}{ Nível de uréia (\%) } \\
\cline { 2 - 5 } & 0 & 1,2 & 2,4 & 3,6 \\
\hline Mistura mineral $^{1}$ & 1,2 & 1,2 & 1,2 & 1,2 \\
Uréia/Sulfato de amônia $^{2}(9: 1)$ & - & 1,2 & 2,4 & 3,6 \\
Farelo de algodão & 40,3 & 30,1 & 19,9 & 9,7 \\
Milho triturado & 58,5 & 67,5 & 76,5 & 85,5
\end{tabular}

${ }^{1}$ Composição percentual: cloreto de sódio - 47,64; fosfato bicálcico - 50,00; sulfato de zinco - 1,50 ; sulfato de cobre - 0,75 ; sulfato de cobalto - 0,05 ; iodato de potássio - 0,06. 
da disponibilidade de matéria seca verde/ha (MSV). A avaliação da forragem ingerida pelos animais foi realizada por meio de extrusa esofágica.

Amostras de fezes e digesta abomasal foram coletadas às $8 \mathrm{~h}$ no $8 \underline{0}$ dia e às $16 \mathrm{~h}$ no $12^{\underline{0}}$ dia do período experimental. As fezes foram coletadas no reto, em quantidades de aproximadamente $200 \mathrm{~g}$, pré-secas em estufa de ventilação forçada $\left(60^{\circ} \mathrm{C}\right)$ por 72 horas e trituradas em moinho de facas com peneira com malha de $1,0 \mathrm{~mm}$, compostas por animal/ período.

A excreção fecal foi estimada utilizando-se óxido crômico, aplicado em dose única diária ( $15 \mathrm{~g} / \mathrm{animal})$, entre o $3 \underline{0}$ e o $12 \underline{0}$ dia do período experimental, calculada com base na razão entre a quantidade do indicador fornecido e sua concentração nas fezes. O indicador foi acondicionado em cartuchos de papel e introduzido diretamente no rúmen (às $11 \mathrm{~h}$ ) dos animais fistulados.

As estimativas do consumo de matéria seca e do fluxo de matéria seca abomasal foram obtidas empregando-se como indicador interno a fibra em detergente ácido indigestível (FDAi), conforme as equações:

$$
\text { (1)CMS }=\frac{[(E F \times C I F)-I S]}{C I F O}+C M S S \text { e } \quad(2) F M A=\frac{E F \times C I F}{C I A B}
$$

em que: $\mathrm{EF}$ = excreção fecal (kg/dia); CIF = concentração do indicador nas fezes $(\mathrm{kg} / \mathrm{kg})$; IS = indicador presente no suplemento (kg/dia); CIFO = concentração do indicador na forragem $(\mathrm{kg} / \mathrm{kg})$; e CMSS = consumo de MS de suplemento (kg/dia); FMA = fluxo de MS abomasal (kg/dia); e CIAB = concentração do indicador na digesta abomasal $(\mathrm{kg} / \mathrm{kg})$.

O consumo foi correlacionado ao peso vivo dos animais utilizando-se como referência o peso médio no período, determinado pela média entre os valores inicial e final de cada período. O pH e a concentração de amônia $\left(\mathrm{NH}_{3}\right)$ ruminal foram determinados por meio de coleta do líquido ruminal, no 14ํㅡㄹ dia do período experimental, 4 horas após o fornecimento dos suplementos. As análises de $\mathrm{pH}$ do líquido ruminal foram realizadas imediatamente após a coleta, em peagâmetro digital. Para determinação de $\mathrm{NH}_{3}$, separou-se uma alíquota de $50 \mathrm{~mL}$, fixada com $1,0 \mathrm{~mL}$ de $\mathrm{H}_{2} \mathrm{SO}_{4}$ (1:1), que foi acondicionada em recipiente de plástico e congelada a $-20^{\circ} \mathrm{C}$.

No $13^{\circ}$ dia do período experimental, foram coletadas amostras spot de urina, em micção espontânea, e de sangue dos animais aproximadamente 4 horas após o fornecimento do suplemento. As amostras de urina (10 mL) foram diluídas em $40 \mathrm{~mL}$ de $\mathrm{H}_{2} \mathrm{SO}_{4} 0,036 \mathrm{~N}$, acondicionadas em potes de plástico e congeladas. As amostras de sangue foram coletadas simultaneamente às de urina, por punção da veia jugular, utilizando-se kits comerciais a vácuo com gel acelerador da coagulação. Em seguida, foram centrifugadas a $4.000 \mathrm{rpm}$, durante 15 minutos, e o soro foi congelado.

Utilizaram-se kits comerciais para a avaliação dos teores de creatinina e uréia nas amostras de urina. O volume urinário foi obtido pela relação entre as excreções diárias de creatinina, adotando-se o valor de 27,36 mg/kg PV (Rennó et al., 2000) e sua concentração nas amostras coletadas.

No 15 - dia do período experimental, amostras de digesta ruminal, para o isolamento de bactérias ruminais, foram coletadas 4 horas após o fornecimento do suplemento. Utilizou-se formaldeído P.A. como agente conservante do líquido ruminal, na proporção de $10 \mathrm{~mL} / \mathrm{L}$ de líquido ruminal. O isolamento das bactérias foi realizado conforme descrito por Cecava et al. (1990) e para a quantificação da proteína microbiana, foram utilizadas as bases púricas como indicadores (Ushida et al., 1985).

As análises laboratoriais foram realizadas de acordo com descrições de Silva \& Queiroz (2002), com exceção das avaliações de FDN e FDA, que seguiram os métodos descritos por Mertens (2002) e Van Soest \& Robertson (1985), respectivamente (Tabela 2).

Tabela 2 - Composição do pasto e dos suplementos

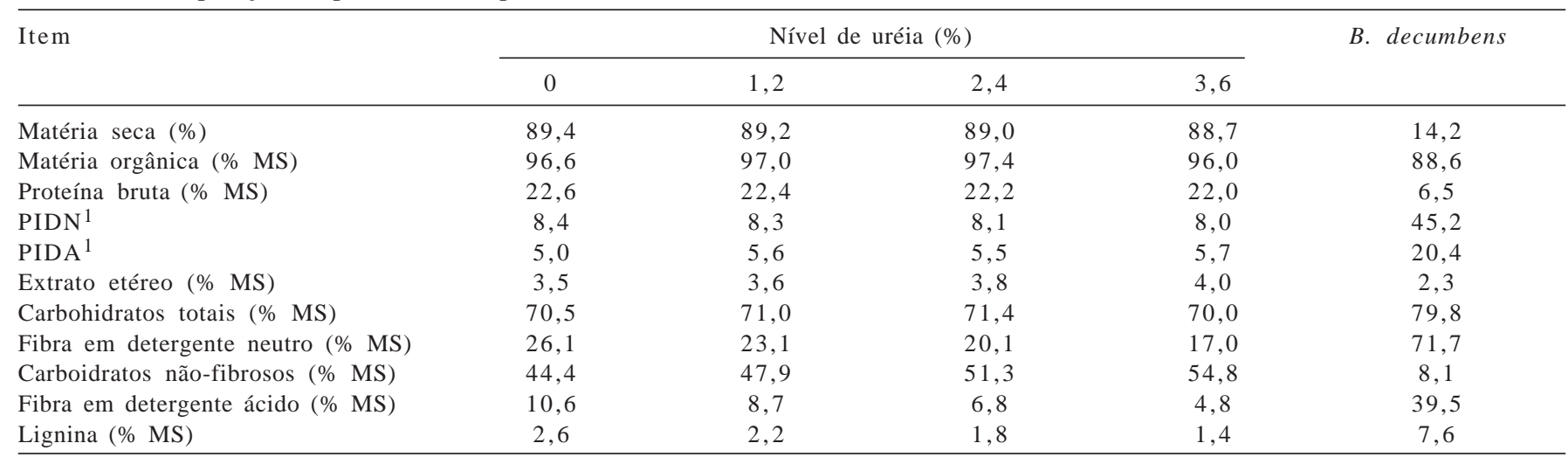

$1 \%$ dos compostos nitrogenados totais; PIDA = proteína insolúvel em detergente ácido; PIDN = proteína insolúvel em detergente neutro. 
O experimento foi analisado segundo delineamento em quadrado latino $4 \times 4$, com quatro níveis de uréia e quatro períodos experimentais. As comparações entre médias foram realizadas pela decomposição da soma de quadrados para tratamentos em contrastes ortogonais relativos aos efeitos de ordem linear, quadrática e cúbica em função dos níveis de uréia nos suplementos com posteriores ajustes de equações de regressão linear. Ressalta-se que, em nenhuma das variáveis estudadas, foram detectados efeitos de ordem cúbica, portanto, foram suprimidos da discussão. Para todos os procedimentos estatísticos, adotou-se 0,05 como limite máximo tolerável para o erro tipo I.

\section{Resultados e Discussão}

As disponibilidades médias de matéria seca total e MSV durante o período experimental foram de 4.794 e $1.308 \mathrm{~kg} / \mathrm{ha}$, respectivamente. A matéria seca total disponível aos animais esteve sempre acima dos valores de 7,0 a 11,0\% do PV dos animais em matéria seca, considerados por Barbosa et al. (2006) necessários para garantir consumo máximo de forragem, menor tempo de pastejo e maior quantidade de forragem degradada no rúmen.

Verificou-se comportamento quadrático $(\mathrm{P}<0,05)$ para os consumos diários de matéria seca total (MST) e de pasto (MSP), matéria orgânica, matéria orgânica de pasto (MOP), proteína bruta, extrato etéreo, FDN, carboidratos totais e carboidratos não-fibrosos nos diferentes níveis de uréia (Tabela 3). As respostas máximas estimadas obtidas sobre os níveis de uréia foram: 2,0\% (10,9kg/dia), 2,3\% (7,1kg/dia),
2,2\% (9,7 kg/dia), 2,3\% (6,3 kg/dia), 1,9\% (1,3 kg/dia), 3,6\% (0,4 kg/dia), 1,9\% (5,8 kg/dia), 2,3\% (8,2 kg/dia) e 2,9\% (4,1 kg/dia), respectivamente, para os consumos de matéria seca total, matéria seca do pasto, matéria orgânica, matéria orgânica do pasto, proteína bruta, extrato etéreo, FDN, carboidratos totais e carboidratos não-fibrosos.

O aumento no consumo de forragem até o nível de 2,4\% de uréia deve-se principalmente à capacidade do nitrogênio não-protéico (NNP) em melhorar a eficiência de digestão da fibra pelo suprimento de amônia ruminal, principal fonte de nitrogênio utilizada pelas bactérias celulolíticas (Russell et al., 1992). Por outro lado, quando adicionada uréia ao suplemento (3,6\%), os animais consumiram aproximadamente 9,0\% menos forragem no nível de 2,4\%. Segundo Köster et al. (1996), esse comportamento indica que as respostas positivas para o consumo de forragem, utilizando suplementos com altos níveis de uréia são limitadas, tanto para a fermentação da forragem quanto para as exigências de NNP da microbiota ruminal.

Os demais nutrientes (proteína bruta, extrato etéreo, FDN, carboidratos totais e carboidratos não-fibrosos) também apresentaram comportamento quadrático, mesmo comportamento apresentado para o consumo de matéria seca total. No caso da FDN, seu teor no suplemento decresceu à medida que o farelo de algodão foi substituído pela uréia, fato que pode também ter contribuído para o menor consumo de FDN nos animais mantidos com maior nível de uréia.

Os consumos de matéria seca total, matéria seca do pasto, matéria orgânica, matéria orgânica do pasto e FDN

Tabela 3 - Consumo de nutrientes em bovinos de corte recebendo suplemento com diversos níveis de uréia

\begin{tabular}{|c|c|c|c|c|c|c|c|c|c|}
\hline \multirow[t]{2}{*}{ Item } & \multicolumn{4}{|c|}{ Nível de uréia } & \multicolumn{3}{|c|}{ Regressão $^{1}$} & \multirow[t]{2}{*}{$\mathrm{r}^{2}$} & \multirow[t]{2}{*}{ CV (\%) } \\
\hline & 0,0 & 1,2 & 2,4 & 3,6 & Contraste & Linear & Quadrático & & \\
\hline \multicolumn{10}{|c|}{$\mathrm{kg} / \mathrm{dia}$} \\
\hline Matéria seca do pasto & 10,1 & 10,3 & 11,0 & 10,4 & 9,92 & 0,99 & $0,25 *$ & 0,80 & 4,9 \\
\hline Matéria seca & 6,3 & 6,7 & 7,3 & 6,7 & 6,22 & 0,79 & $0,17 *$ & 0,82 & 4,6 \\
\hline Matéria orgânica & 9,0 & 9,4 & 9,9 & 9,4 & 8,99 & 0,67 & $0,15 *$ & 0,82 & 2,9 \\
\hline Matéria orgânica do pasto & 5,6 & 5,9 & 6,5 & 6,0 & 5,50 & $0,69 *$ & $0,15 *$ & 0,83 & 4,6 \\
\hline Proteína bruta & 1,2 & 1,2 & 1,3 & 1,2 & 1,22 & 0,04 & $0,01 *$ & 0,75 & 1,5 \\
\hline Extrato etéreo & 0,3 & 0,3 & 0,4 & 0,3 & 0,31 & $0,03 *$ & $0,004 *$ & 0,96 & 2,1 \\
\hline Fibra em detergente neutro & 5,4 & 5,6 & 5,9 & 5,4 & 5,38 & 0,47 & $0,12 *$ & 0,72 & 4,6 \\
\hline Carboidratos totais & 7,5 & 7,9 & 8,4 & 7,7 & 7,48 & $0,64^{*}$ & $0,14 *$ & 0,82 & 3,1 \\
\hline Carboidratos não-fibrosos & 2,3 & 3,5 & 4,0 & 3,8 & 2,29 & $1,26^{*}$ & $0,22 *$ & 0,95 & 5,1 \\
\hline \multicolumn{10}{|c|}{$\% \mathrm{PV}$} \\
\hline Matéria seca total & 2,2 & 2,2 & 2,4 & 2,1 & 2,18 & 0,15 & $0,04 *$ & 0,82 & 3,7 \\
\hline Matéria seca do pasto & 1,4 & 1,4 & 1,6 & 1,4 & 1,14 & 0,14 & $0,03 *$ & 0,85 & 4,8 \\
\hline Matéria orgânica & 1,9 & 2,0 & 2,2 & 1,9 & 1,93 & 0,19 & $0,05 *$ & 0,88 & 4,8 \\
\hline Matéria orgânica do pasto & 1,2 & 1,3 & 1,4 & 1,2 & 1,19 & 0,17 & $0,04 *$ & 0,87 & 4,6 \\
\hline Fibra em detergente neutro & 1,2 & 1,2 & 1,3 & 1,1 & 1,18 & 0,08 & $0,03 *$ & 0,84 & 5,2 \\
\hline
\end{tabular}

* Significativo a 5\% de probabilidade pelo teste T. CV = coeficiente de variação. 
expressos em \%PV também apresentaram comportamento quadrático $(\mathrm{P}<0,05)$, com respostas máximas estimadas obtidas nos níveis de uréia de 1,80\% (2,3\% PV), 2,2\% (1,3\% PV), $1,9 \%$ (2,1\% PV), 1,9\% (1,3\% PV) е 1,5\% (1,2\% PV), respectivamente.

Apenas a digestão total da matéria orgânica (Tabela 4) aumentou $(\mathrm{P}<0,05)$ com os níveis de uréia. Segundo Huntington \& Archibeque (1999), os efeitos positivos sobre a digestibilidade da matéria orgânica com a inclusão de uréia podem estar relacionados ao aumento na taxa de crescimento dos microrganismos ruminais e ao conseqüente aproveitamento dos produtos finais da fermentação, por causa do nitrogênio disponível no rúmen.

Com exceção da digestibilidade ruminal de FDN $(\mathrm{P}<0,05)$, não houve efeito do nível de uréia sobre as digestibilidades ruminais dos nutrientes. A resposta máxima para a digestibilidade ruminal da FDN estimada para os níveis de uréia foi de 2,2\% (88,7\%).

A redução de aproximadamente $9,0 \%$ na digestibilidade ruminal da FDN nos animais que receberam suplemento com maior nível de uréia pode estar relacionada à reduzida disponibilidade de aminoácidos, peptídeos ou outros fatores que aumentam o crescimento dos microrganismos que degradam a fibra conforme se aumenta a participação da uréia, que é constituída de NNP (Griswold et al., 2003). Ressalta-se que o valor negativo observado para a digestibilidade aparente ruminal do extrato etéreo indica síntese de lipídeos microbianos.

Os valores médios observados para o $\mathrm{pH}$ ruminal (Figura 1) não foram influenciados pelos níveis de uréia e estiveram entre 6,30 e 6,55. Esses valores sempre se mantiveram superiores a 6,10 , considerado limite inibitório à

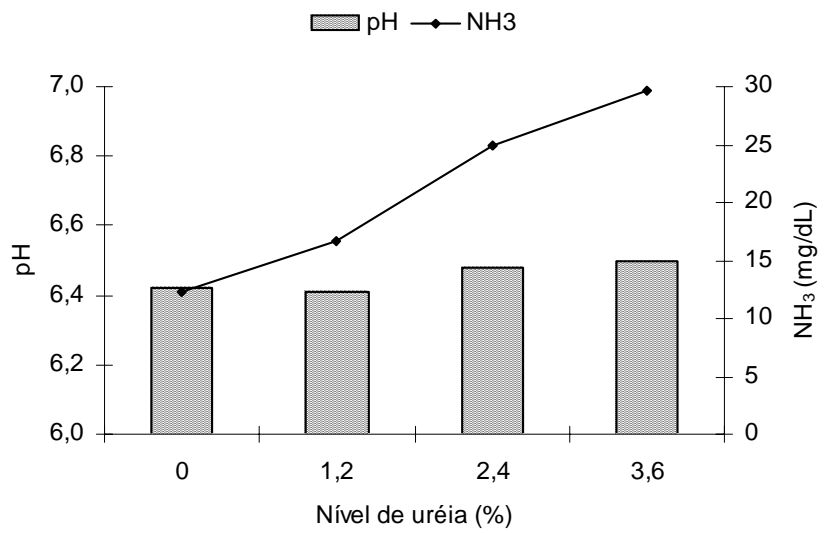

Figura 1 - Estimativas do pH e das concentrações de amônia $\left(\mathrm{NH}_{3}\right)$ do líquido ruminal em cada nível de uréia no suplemento. $\hat{Y}_{\mathrm{NH}_{3}}=11,8590+5,0127 \mathrm{NU}\left(\mathrm{r}^{2}=0,98\right)$.

Tabela 4 - Digestibilidade dos nutrientes da dieta em bovinos recebendo suplemento com diversos níveis de uréia

\begin{tabular}{|c|c|c|c|c|c|c|c|c|c|}
\hline \multirow[t]{2}{*}{ Nutriente } & \multicolumn{4}{|c|}{ Nível de uréia } & \multicolumn{3}{|c|}{ Regressão $^{1}$} & \multirow[t]{2}{*}{$\mathrm{r}^{2}$} & \multirow[t]{2}{*}{$\mathrm{CV}(\%)$} \\
\hline & 0,0 & 1,2 & 2,4 & 3,6 & Contraste & Linear & Quadrático & & \\
\hline \multicolumn{10}{|c|}{ Total } \\
\hline Matéria seca ${ }^{2}$ & 70,4 & 71,4 & 72,9 & 71,8 & 71,63 & ns & ns & - & 2,4 \\
\hline Matéria orgânica² & 62,8 & 64,7 & 64,3 & 66,8 & 62,94 & $0,97^{*}$ & ns & 0,83 & 3,1 \\
\hline Proteína bruta ${ }^{2}$ & 59,4 & 61,6 & 63,7 & 59,1 & 60,95 & ns & ns & - & 5,4 \\
\hline Extrato etéreo ${ }^{2}$ & 75,0 & 75,0 & 72,7 & 73,8 & 74,13 & ns & ns & - & 6,4 \\
\hline Fibra em detergente neutro ${ }^{2}$ & 59,4 & 59,0 & 59,8 & 61,2 & 59,85 & ns & ns & - & 5,2 \\
\hline Carboidratos totais ${ }^{2}$ & 63,8 & 65,4 & 64,8 & 67,9 & 65,48 & ns & ns & - & 3,7 \\
\hline Carboidratos não-fibrosos ${ }^{2}$ & 77,2 & 88,0 & 86,0 & 89,2 & 85,10 & ns & ns & - & 8,2 \\
\hline \multicolumn{10}{|c|}{ Ruminal } \\
\hline Matéria seca ${ }^{2}$ & 68,8 & 68,0 & 69,6 & 68,1 & 68,63 & ns & ns & - & 6,1 \\
\hline Matéria orgânica ${ }^{2}$ & 77,6 & 74,5 & 75,7 & 73,1 & 75,23 & ns & ns & - & 7,8 \\
\hline Proteína bruta ${ }^{3}$ & 29,8 & 25,1 & 35,2 & 30,6 & 30,18 & ns & ns & - & 18,4 \\
\hline Extrato etéreo ${ }^{3}$ & $-8,2$ & $-5,5$ & $-3,6$ & $-17,7$ & $-8,75$ & ns & ns & - & 405,0 \\
\hline Fibra em detergente neutro ${ }^{2}$ & 81,0 & 82,3 & 93,3 & 83,3 & 79,50 & 8,49 & $1,94 *$ & 0,82 & 7,4 \\
\hline Carboidratos totais ${ }^{2}$ & 85,9 & 83,2 & 82,9 & 80,9 & 83,23 & ns & ns & - & 10,4 \\
\hline Carboidratos não-fibrosos ${ }^{2}$ & 76,6 & 75,1 & 76,0 & 81,4 & 77,28 & ns & ns & - & 21,7 \\
\hline \multicolumn{10}{|c|}{ Intestinal } \\
\hline Matéria seca ${ }^{2}$ & 31,2 & 32,0 & 30,4 & 31,9 & 31,38 & ns & ns & - & 13,3 \\
\hline Matéria orgânica² & 22,4 & 25,4 & 24,2 & 26,9 & 24,73 & ns & ns & - & 23,8 \\
\hline Proteína bruta ${ }^{3}$ & 41,6 & 48,6 & 42,1 & 40,4 & 43,18 & ns & ns & - & 21,3 \\
\hline Extrato etéreo ${ }^{3}$ & 73,1 & 77,3 & 73,1 & 76,7 & 75,05 & ns & ns & - & 10,7 \\
\hline Fibra em detergente neutro ${ }^{2}$ & 14,4 & 12,9 & 13,6 & 13,9 & 13,70 & ns & ns & - & 54,9 \\
\hline Carboidratos totais ${ }^{2}$ & 14,1 & 16,8 & 17,0 & 19,1 & 16,75 & ns & ns & - & 20,5 \\
\hline Carboidratos não-fibrosos ${ }^{2}$ & 23,4 & 24,9 & 24,0 & 19,4 & 22,93 & ns & ns & - & 48,6 \\
\hline
\end{tabular}

* Significativo a $5 \%$ de probabilidade pelo teste $\mathrm{T} ;{ }^{2} \%$ do total digerido; ${ }^{3} \%$ quantidade que chegou no local. 
adequada atividade dos microrganismos celulolíticos (Hoover, 1986).

Por outro lado, a concentração de $\mathrm{NH}_{3}$ aumentou linearmente $(\mathrm{P}<0,05)$ com os níveis de uréia, em virtude da alta taxa de hidrólise da uréia, refletindo o fornecimento de uma fonte prontamente disponível de nitrogênio. Sabe-se que os níveis de $\mathrm{NH}_{3}$ do líquido ruminal são importantes, visto que o crescimento microbiano é altamente dependente da quantidade de substrato e da fermentação da matéria orgânica no rúmen. Os valores médios (Tabela 5) observados estiveram acima dos 5,0 mg de $\mathrm{NH}_{3} / \mathrm{dL}$ de líquido ruminal sugeridos por Satter \& Slyter (1974) como não limitantes à fermentação microbiana; e dos 10,0 mg/dL sugeridos por Leng (1990) como ótimo para apropriada fermentação em condições tropicais. Desta forma, a concentração de $\mathrm{NH}_{3}$ ruminal não limitou a fermentação em nenhum dos níveis de uréia.

As concentrações de NUS aumentaram linearmente com os níveis de uréia nos suplementos $(\mathrm{P}<0,05)$. De forma contrária, Magalhães et al. (2005) trabalharam com novilhos em confinamento e não observaram efeitos dos níveis de uréia nos concentrados sobre o nitrogênio sérico. O nitrogênio uréico seguiu o mesmo comportamento e evidencia a sensível redução no aproveitamento dietético do nitrogênio. Segundo Harmeyer \& Martens (1980), a quantidade de nitrogênio excretada na urina é influenciada principalmente pela sua concentração sanguínea. O comportamento da concentração de $\mathrm{NH}_{3}$ ruminal (Figura 1) juntamente com do NUS corrobora a afirmação de Russell et al. (1992) de que a produção excessiva de $\mathrm{NH}_{3}$ e sua conseqüente absorção ruminal aumentam a excreção urinária de nitrogênio. Além disso, a quantidade ou degradabilidade da proteína dietética afeta o metabolismo da uréia (Huntington et al., 2001), fato evidenciado pelas alterações nas concentrações NUS e NU.

A energia necessária para a formação de uréia a partir do excesso de proteína decresce à razão energia líquida/ energia metabolizável, é direcionada à formação de calor corporal (NRC, 2000) e pode estar relacionada à melhor utilização de aminoácidos pelo fígado, com efeitos na neogliconeogênese e trocas de carbono via ciclo de Krebs. Segundo Poppi \& McLennan (1995), a dissipação de calor corporal constitui grande limitação para a produção de bovinos nos trópicos. Neste contexto, este fato poderia explicar a redução no consumo de matéria seca dos animais ao receberem suplemento com 3,6\% de uréia (Tabela 3), demonstrando que tenderam a reduzir a ingestão de alimentos e aumentar concomitantemente a demanda energética para ativação dos mecanismos fisiológicos de dissipação de calor corporal a taxas mais confortáveis.

Os níveis de uréia não afetaram $(\mathrm{P}>0,05)$ os níveis de nitrogênio microbiano. Magalhães et al. (2005) também não verificaram efeito do nível de uréia no Nmic de animais em confinamento. O crescimento microbiano depende da quantidade de energia proveniente da fermentação ruminal e, segundo Russell et al. (1992), aumenta quando as taxas de fermentação do amido e proteínas estão sincronizadas. Assim, o suprimento de nutrientes é altamente dependente de uma dieta adequadamente balanceada, para permitir aumento da síntese microbiana, possível de ser suprida exclusivamente pela forrageira somente em um período curto do ano e se a área de pastagem estiver bem manejada. Neste contexto, é possível a adequação da pastagem por maior período de tempo com a utilização de suplementos.

Desta forma, pode-se inferir que não houve limitações para o crescimento microbiano, visto que a eficiência microbiana, em qualquer forma de expressão, não foi influenciada pelos níveis de uréia nos suplementos $(\mathrm{P}>0,05)$. O valor médio de eficiência microbiana, expressa em g de PBmin/100g NDT (11,9), foi pouco inferior à eficiência proposta pelo NRC (2000), de $13 \mathrm{~g}$ PBmic/100g NDT. No entanto, foi bem próximo ao de 12 g PBmi/100g NDT

Tabela 5 - Níveis de nitrogênio sérico e urinário, fluxo de nitrogênio microbiano e eficiência microbiana em bovinos de corte recebendo suplemento com diversos níveis de uréia

\begin{tabular}{|c|c|c|c|c|c|c|c|c|c|}
\hline \multirow[t]{2}{*}{ Nutriente } & \multicolumn{4}{|c|}{ Nível de uréia } & \multicolumn{3}{|c|}{ Regressão $^{1}$} & \multirow[t]{2}{*}{$r^{2}$} & \multirow[t]{2}{*}{ CV (\%) } \\
\hline & 0,0 & 1,2 & 2,4 & 3,6 & Contraste & Linear & Quadrático & & \\
\hline Nitrogênio sérico (mg/dL) & 18,6 & 19,7 & 20,4 & 22,7 & 18,34 & $1,11^{*}$ & ns & 0,95 & 11,7 \\
\hline Nitrogênio urinário (g/dL) & 54,3 & 59,6 & 66,1 & 71,1 & 54,24 & $4,74^{*}$ & ns & 0,99 & 11,2 \\
\hline \multirow[t]{2}{*}{ Nitrogênio microbiano (g/dia) } & 57,5 & 59,7 & 61,8 & 60,6 & ns & ns & ns & - & 22,4 \\
\hline & \multicolumn{4}{|c|}{ Eficiência microbiana } & & & & & \\
\hline A (g Nmic/kg MODR) & 25,4 & 22,9 & 22,9 & 23,1 & ns & ns & ns & - & 23,8 \\
\hline B (g Nmic/kg CTDR) & 26,1 & 24,3 & 24,8 & 24,4 & ns & ns & ns & - & 20,6 \\
\hline C (g PBmic/100 g de NDT) & 12,2 & 12,1 & 11,8 & 11,7 & ns & ns & ns & - & 23,9 \\
\hline
\end{tabular}

*Significativo a $5 \%$ de probabilidade pelo teste $\mathrm{T}$. 
recomendado por Valadares Filho et al. (2006) como referência para condições tropicais. Ressalta-se que a recomendação do NRC (2000) é uma generalização que nem sempre se aplica a todas condições nutricionais. Com base no próprio NRC (2000), dietas com níveis de consumo variando de 1,9 a $2,1 \%$ do PV e NDT entre $70-80,0 \%$, a eficiência microbiana estaria entre 90,0-110,0 g PBmic/kg NDT. Desta forma, os valores médios estimados de síntese microbiana deste estudo são adequados e aplicáveis.

Paixão et al. (2006), trabalhando com animais em confinamento recebendo níveis crescentes de uréia, também não observaram efeitos significativos sobre a síntese de proteína microbiana. De forma similar, Magalhães etal. (2005) encontraram valores numericamente superiores para síntese de proteína microbiana nos menores níveis de uréia no concentrado. Por outro lado, Rennó et al. (2008) observaram redução linear na eficiência microbiana à medida que elevaram o nível de uréia no concentrado. Segundo estes autores,este comportamento pode estar relacionado à redução no fluxo de nitrogênio microbiano em dietas com concentrados ricos em uréia.

De acordo com o NRC (2001), há evidências de que aminoácidos e especialmente peptídeos estimulam a produção de microrganismos que crescem em fontes energéticas rapidamente degradáveis. Entretanto, quando os substratos energéticos são fermentados lentamente, esta estimulação não ocorre.

\section{Conclusões}

Bovinos em fase de terminação consumindo $4,0 \mathrm{~kg}$ de suplemento com nível de uréia próximo de 2,4\% aumentam o consumo de forragem. Com exceção da digestibilidade aparente total de matéria orgânica e da digestibilidade ruminal da FDN, o aumento do nível de uréia no suplemento não altera as digestibilidades total, ruminal e intestinal dos demais nutrientes da dieta. O aumento do nível de uréia nos suplementos aumenta as concentrações de $\mathrm{NH}_{3}$ ruminal e de nitrogênio uréico sérico e urinário dos animais, o que reduz o aproveitamento do nitrogêno dietético. A eficiência microbiana não é afetada pelos níveis de uréia no suplemento.

\section{Literatura Citada}

BARBOSA, M.A.A.F.; NASCIMENTO JR., D.; CECATO, U. Dinâmica da pastagem e desempenho de novilhos em pastagem de capim tanzânia sob diferentes ofertas de forragem. Revista Brasileira de Zootecnia, v.35, n.4, p.1594-1600, 2006 (supl.).

CECAVA, M.J.; MERCHEN, N.R.; GAY, L.C. et al. Composition of ruminal bacteria harvest from steers as influenced by dietary energy level, feeding frequency, and isolation techniques Journal of Dairy Science, v.73, n.9, p.2480-2488, 1990.

GRISWOLD, K.E.; APGAR, G.A.; BOUTON, J. et al. Effects of urea infusion and ruminal degradable protein concentration on microbial growth, digestibility and fermentation in continuous culture. Journal of Animal Science, v.81, n.2, p.329-336, 2003.

HARMEYER, J.; MARTENS, H. Aspects of urea metabolism with reference to the goat. Journal of Dairy Science, v.63, n.10, p.1707-1728, 1980.

HOOVER, W.H. Chemical factors involved in ruminal fiber digestion. Journal of Dairy Science, v.69, n.10, p.2755-2766, 1986.

HUNTINGTON, G.B.; ARCHIBEQUE, S.L. Practical aspects of urea and ammonia metabolism in ruminants. In: AMERICAN SOCIETY OF ANIMAL SCIENCE, 1999, Raleigh. Proceedings... Raleigh: American Society of Animal Science, 1999. p.1-11.

HUNTINGTON, G.B.; POORE, M.; HOPKINS, B. et al. Effect of ruminal protein degradability on growth and $\mathrm{N}$ metabolism in growing beef steers.Journal of Animal Science, v.79, n.3, p.533-541, 2001.

KÖSTER, H.H.; COCHRAN, R.C.; TITGEMEYER, E.C. et al. Effect of increasing degradable intake protein on intake and digestion of low-quality, tall grass prairie forage by beef cows. Journal of Animal Science, v.74, n.9, p.2478-2481, 1996.

LENG, R.A. Factors affecting the utilization of "poor-quality" forages by ruminants particularly under tropical conditions. Nutrition Research Review, v.3, n.3, p.277-303, 1990.

MAGALHÃES, K.A.; VALADARES FILHO, S.C.; VALADARES, R.F.D. et al. Produção de proteína microbiana, concentração plasmática de uréia e excreções de uréia em novilhos alimentados com diferentes níveis de uréia ou casca de algodão. Revista Brasileira de Zootecnia, v.34, n.4, p.1400-1407, 2005.

MERTENS, D.R. Gravimetric determination of amylase treated neutral detergent fiber in feeds with refluxing in beakers or crucibles: collaborative study. Journal of AOAC International, v.85, n.6, p.1212-1240, 2002.

MOSCARDINI, S.; WRIGHT, T.C.; LUIMES, P.H. et al. Effects of rumen-undegradable protein and feed intake on purine derivate and urea nitrogen: comparison with predictions from the Cornell Net Carbohydrate and protein system. Journal of Dairy Science, v.81, n.9, p.2421-2329, 1998.

MORAES, E.H.B.K.; PAULINO, M.F.; ZERVOUDAKIS, J.T. Associação de diferentes fontes energéticas e protéicas em suplementos múltiplos na recria de novilhos mestiços sob pastejo no período da seca. Revista Brasileira de Zootecnia, v.35, n.3, p.914-930, 2006.

NATIONAL RESEARCH COUNCIL - NRC. Nutrient requirements of beef cattle. 7.rev.ed. Washington, D.C.: National Academy Press, 2000. 242p.

PAIXÃO, M.L.; VALADARES FILHO, S.C.; LEÃO, M.I. et al. Uréia em dietas para bovinos: consumo, digestibilidade dos nutrientes, ganho de peso, características de carcaça e produção microbiana. Revista Brasileira de Zootecnia, v.35, n.6, p.2451-2460, 2005.

POPPI, D.P.; McLENNAN, S.R. Protein and energy utilization by ruminants at pasture. Journal of Animal Science, v.73, n.1, p.278-290, 1995.

RENNÓ, L.N.; VALADARES, R.F.; VALADARES FILHO, S.C. et al. Concentração plasmática de uréia e excreções de uréia e creatinina em novilhos. Revista Brasileira de Zootecnia, v.29, n.45, p.1235-1243, 2000.

RENNÓ, L.N.; VALADARES FILHO, S.C.; VALADARES, R.F.D. et al. Níveis de uréia na ração de novilhos de quatro grupos genéticos: consumo e digestibilidades totais. Revista Brasileira de Zootecnia, v.34, n.5, p.1775-1785, 2005.

RENNÓ, L.N.; VALADARES FILHO, S.C.; VALADARES, R.F.D. et al. Níveis de uréia na ração de novilhos de quatro grupos 
genéticos: estimativa da produção de proteína microbiana por meio dos derivados de purinas na urina utilizando duas metodologias de coleta. Revista Brasileira de Zootecnia, v.37, n.3, p.546-555, 2008.

RUSSELL, J.B.; O'CONNOR, J.D.; FOX, D.J. et al. A net carbohydrate and protein system for evaluating cattle diets: I. Ruminal fermentation. Journal of Animal Science, v.70, n.11, p.3551-3561, 1992.

SATTER, L.D.; SLYTER, L.L. Effect of ammonia concentration on rumen microbial protein in vitro. British Journal of Nutrition, v.32, n.2, p.199-208, 1974.

SILVA, D.J.; QUEIROZ, A.C. Análise de alimentos: métodos químicos e biológicos. 3.ed.Viçosa, MG: Editora UFV, 2002. 165p.
USHIDA, K.; LASSALAS, B.; JOUANY, J.P. Determination of assay parameters for RNA analysis in bacterial and duodenal samples by spectrophotometry. Influence of sample treatment and preservation. Reproduction and Nutrition Development, v.25, n.6, p.1037-1046, 1985.

VALADARES FILHO, S.C.; PINA, D.S.; CHIZZOTTI, M.L. et al. Degradação ruminal da proteína dos alimentos e síntese de proteína microbiana. In: VALADARES FILHO, S.C.; PAULINO, P.V.R; MAGALHÃES, K.A. (Eds.) Exigências nutricionais de zebuínos e tabelas de composição de alimentos BRCorte. Viçosa, MG: Suprema Gráfica, 2006. 142p.

Van SOEST, P.J.; ROBERTSON, J.B. Analysis of forages and fibrous foods. Ithaca: Cornell University, 1985. 202p. 